\title{
On the Arrangement of Pentagonal Columns in Tetragonal Tungsten Bronze-Type Nb18W16093
}

\section{Journal Article}

Author(s):

Krumeich, Frank (i)

Publication date:

2021-12-05

Permanent link:

https://doi.org/10.3929/ethz-b-000522574

Rights / license:

Creative Commons Attribution 4.0 International

Originally published in:

Crystals 11(12), https://doi.org/10.3390/cryst11121514 


\title{
Article \\ On the Arrangement of Pentagonal Columns in Tetragonal Tungsten Bronze-Type $\mathrm{Nb}_{18} \mathrm{~W}_{16} \mathrm{O}_{93}$
}

\author{
Frank Krumeich
}

Citation: Krumeich, F. On the Arrangement of Pentagonal Columns in Tetragonal Tungsten Bronze-Type $\mathrm{Nb}_{18} \mathrm{~W}_{16} \mathrm{O}_{93}$. Crystals 2021, 11, 1514 https://doi.org/10.3390/cryst11121514

Academic Editors: Bin Hua, Georgios Dimitrakopulos and Meng Li

Received: 11 November 2021 Accepted: 3 December 2021 Published: 5 December 2021

Publisher's Note: MDPI stays neutra with regard to jurisdictional claims in published maps and institutional affiliations.

Copyright: (C) 2021 by the author. Licensee MDPI, Basel, Switzerland. This article is an open access article distributed under the terms and conditions of the Creative Commons Attribution (CC BY) license (https:/ / creativecommons.org/licenses/by/ $4.0 /)$.
Laboratory of Inorganic Chemistry, Department of Chemistry and Applied Biosciences, ETH Zürich, 8093 Zürich, Switzerland; krumeich@inorg.chem.ethz.ch

\begin{abstract}
The evaluation of HAADF-STEM images of a sample with the composition $\mathrm{Nb}_{18} \mathrm{~W}_{16} \mathrm{O}_{93}$ provided new insights into its real structure. The basic structure comprises an intact octahedral framework of the tetragonal tungsten bronze (TTB) type. The partial occupation of the pentagonal tunnels (PT) by metal-oxygen strings determines the oxygen-to-metal ratio $(\mathrm{O} / \Sigma \mathrm{M}$ with $\mathrm{M}=\mathrm{Nb}, \mathrm{W})$. For a large area, the $\mathrm{O} / \Sigma \mathrm{M}$ was determined to be 2.755 , which is bigger than the value of $\mathrm{Nb}_{18} \mathrm{~W}_{16} \mathrm{O}_{93}$, which is $\mathrm{O} / \Sigma \mathrm{M}=2.735$. To a large extent, the three-fold TTB superstructure of $\mathrm{Nb}_{8} \mathrm{~W}_{9} \mathrm{O}_{47}$ with a high oxygen content is present $(\mathrm{O} / \Sigma \mathrm{M}=2.765)$. In addition, a new four-fold TTB superstructure was found in small domains. $\mathrm{Nb}_{12} \mathrm{~W}_{11} \mathrm{O}_{63}$ with an $\mathrm{O} / \Sigma \mathrm{M}=2.739$ obviously accommodates part of the sample's metal excess compared to the stable phase $\mathrm{Nb}_{8} \mathrm{~W}_{9} \mathrm{O}_{47}$.
\end{abstract}

Keywords: niobium tungsten oxide; pentagonal tunnels; tetragonal tungsten bronze; high-angle annular dark field detector; scanning transmission electron microscopy; HAADF-STEM; twinning; superstructure; battery material

\section{Introduction}

At present, there is a broad interest in niobium tungsten oxides, since they have potential applications as high-performance anode materials in lithium-ion batteries. The recent worldwide research activities were induced in 2018 by a report of extremely fast reversible $\mathrm{Li}$ exchange and high cycling stability for the block-type phase $\mathrm{Nb}_{16} \mathrm{~W}_{5} \mathrm{O}_{55}$ and for a sample with the composition $\mathrm{Nb}_{18} \mathrm{~W}_{16} \mathrm{O}_{93}$; the structure of $\mathrm{Nb}_{18} \mathrm{~W}_{16} \mathrm{O}_{93}$ was found to be based on the tetragonal tungsten bronze (TTB) type [1]. This structure type comprises corner-sharing octahedra $\mathrm{MO}_{6}$ that are arranged in such a way that trigonal, square, and pentagonal tunnels arise (Figure 1, bottom left). In the structure of $\mathrm{Nb}_{8} \mathrm{~W}_{9} \mathrm{O}_{47}$, one third of the pentagonal tunnels (PTs) are systematically occupied by metal-oxygen (MO) strings, resulting in a three-fold superstructure of the TTB type (Figure 1, top). The metal inside the PT has a pentagonal bi-pyramidal coordination by oxygen. The unit comprising this polyhedron and the five equatorially connected octahedra is designated a pentagonal column (PC) [2]. Two of such PCs are grouped into pairs by sharing a square of octahedra (so-called diamond link [2]). Four orientations of these PC pairs are possible in the TTB framework, and, at one time, two of them occur in each of the two unit cell orientations of the $\mathrm{Nb}_{8} \mathrm{~W}_{9} \mathrm{O}_{47}$ structure (Figure 1). The three-fold TTB superstructure realized in $\mathrm{Nb}_{8} \mathrm{~W}_{9} \mathrm{O}_{47}$ exhibits high thermodynamic stability, apparently because the interactions between the MO strings inside the TTB substructure are optimized in this arrangement. Iijima and Allpress postulated the following rules for the stable dense packing of PCs [3]: (i) the PTs directly adjacent to a PC $\left(\mathrm{d}_{\mathrm{PC}-\mathrm{PT}} \approx 0.6-0.65 \mathrm{~nm}\right)$ remain empty; (ii) one of the two PTs with the next-nearest distance to a PC ( $\left.\mathrm{d}_{\mathrm{PC}-\mathrm{PT}} \approx 0.9 \mathrm{~nm}\right)$ is occupied, forming a pair of diamond-linked PCs. These rules are strictly obeyed in the structure of $\mathrm{Nb}_{8} \mathrm{~W}_{9} \mathrm{O}_{47}$. Therefore, any deviation from the composition of $\mathrm{M}_{17} \mathrm{O}_{47}$ $(\mathrm{M}=\mathrm{Nb}, \mathrm{W})$ leads to a less ordered real structure. The occupation of directly adjacent PTs, which breaches the first rule, has rarely been observed in TTB-type niobium tungsten oxides 
up to now. In contrast, the second rule is strictly valid for the composition of $\mathrm{M}_{17} \mathrm{O}_{47}$ only, and chains of diamond-linked PCs have frequently been observed in W-richer structural variants, such as $\mathrm{Nb}_{6} \mathrm{~W}_{8} \mathrm{O}_{39}$ (Figure 1) [4].

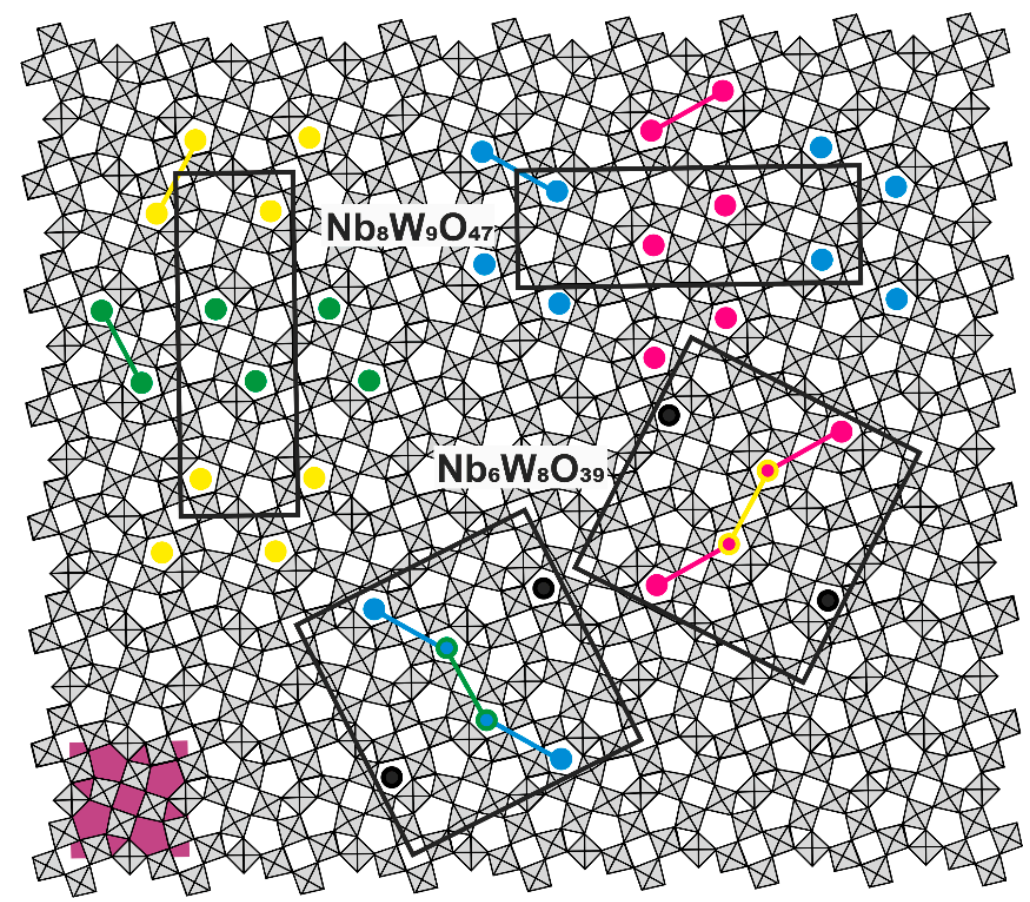

Figure 1. Structural models of $\mathrm{Nb}_{8} \mathrm{~W}_{9} \mathrm{O}_{47}$ and $\mathrm{Nb}_{6} \mathrm{~W}_{8} \mathrm{O}_{39}$ in projection along [1]. Two possible orientations of both structures are shown (unit cells are framed). Filled pentagonal tunnels (PTs) are represented by filled circles. Pairs of filled PTs (filled circles of same color) are connected via the diamond link (some marked by colored lines). A TTB subcell with composition $\mathrm{M}_{10} \mathrm{O}_{30}(\mathrm{M}=\mathrm{Nb}, \mathrm{W})$ is colored purple.

In 1979, Li-containing phases, such as $\mathrm{Li}_{x} \mathrm{Nb}_{8} \mathrm{~W}_{9} \mathrm{O}_{47}$ with $\mathrm{x}=2$ and 4 , could be synthesized by the reaction of $\mathrm{LiNbO}_{3}$ and $\mathrm{WO}_{3}$ [5]. In 1998, the insertion of $\mathrm{Li}$ into $\mathrm{Nb}_{8} \mathrm{~W}_{9} \mathrm{O}_{47}$, by both electrochemical and chemical reactions, could be achieved [6]. A reversible electrochemical uptake of up to $20 \mathrm{Li}$ ions per formula unit was reported for $\mathrm{Nb}_{8} \mathrm{~W}_{9} \mathrm{O}_{47}$ and for the not fully oxidized members of the solid solution series $\mathrm{Nb}_{8-\mathrm{x}} \mathrm{W}_{9+\mathrm{x}} \mathrm{O}_{47}(1 \leq \mathrm{x} \leq 6)$ [7]. As already mentioned above, the electrochemical investigations on TTB-type NbW oxides gained momentum after the study on $\mathrm{Nb}_{18} \mathrm{~W}_{16} \mathrm{O}_{93}$ had been published by Griffith et al. in 2018 [1]. Several follow-up investigations confirmed the outstanding electrochemical performance of samples with this composition [8-13]. The orthorhombic structure $\mathrm{Nb}_{18} \mathrm{~W}_{16} \mathrm{O}_{93}$ was proposed by Stephenson in 1968 to explain the split reflections observed in higher-order Laue zones of a twinned crystal with the composition $\mathrm{Nb}_{12} \mathrm{~W}_{11} \mathrm{O}_{63}\left(6 \mathrm{Nb}_{2} \mathrm{O}_{5}: 11 \mathrm{WO}_{3}\right)$ [14]. For this composition, congruent melting was found in the course of the exploration of the phase diagram $\mathrm{Nb}_{2} \mathrm{O}_{5} / \mathrm{WO}_{3}$ by Roth and Waring [15]. The structure of the hypothetical $\mathrm{Nb}_{18} \mathrm{~W}_{16} \mathrm{O}_{93}$ could not be confirmed, neither by single-crystal $\mathrm{X}$-ray diffraction nor by transmission electron microscopy studies $[3,16,17]$. As both the structural model of $\mathrm{Nb}_{18} \mathrm{~W}_{16} \mathrm{O}_{93}$ and the well-established phase $\mathrm{Nb}_{8} \mathrm{~W}_{9} \mathrm{O}_{47}$ are described by a three-fold TTB superstructure with similar symmetry and practically the same unit cell metric, the differentiation of the two structures by powder XRD is difficult, but possible, if a comparative Rietveld refinement is performed [18]. The difference between these structures is the occupation of PTs in the TTB host lattice, and, thus, the appropriate characterization method is to image the metal positions in the ab plane by high-resolution transmission electron microscopy (HRTEM) $[3,19]$ or by high-angle annular dark field scanning transmission electron microscopy (HAADF-STEM) [20-22]. No evidence for the hitherto assumed structural model for $\mathrm{Nb}_{18} \mathrm{~W}_{16} \mathrm{O}_{93}$ was found in the HAADF-STEM images of a sample 
with this composition. Instead, the observed occupation of the PTs points to a complex intergrowth of two TTB-type phases, as reported in this article.

\section{Materials and Methods}

\subsection{Synthesis}

The sample with composition $\mathrm{Nb}_{18} \mathrm{~W}_{16} \mathrm{O}_{93}$ was prepared by the solid-state reaction of $\mathrm{Nb}_{2} \mathrm{O}_{5}$ and $\mathrm{WO}_{3}$ powders (molar ratio $\mathrm{Nb}_{2} \mathrm{O}_{5}: \mathrm{WO}_{3}=9: 16$ ). After grinding the powders in an agate mortar, the resulting mixture was pressed into pellets and then annealed in a $\mathrm{Pt}$ crucible covered with a Pt lid at $700{ }^{\circ} \mathrm{C}$ for $12 \mathrm{~h}$ followed by $1200{ }^{\circ} \mathrm{C}$ for $12 \mathrm{~h}$. For details, see [12].

\subsection{Electron Microscopy}

Scanning transmission electron microscopy images (STEM) were recorded on a JEMARM300F (JEOL, Japan) using a high-angle annular dark field (HAADF) detector, as described elsewhere [12].

\section{Results}

The HAADF-STEM images of all the crystal fragments observed along the short crystallographic $\mathbf{c}$ axis reveal a defect-free TTB substructure (Figures 2a and 3a and Figure 5a). A close examination of the images shows that most the PTs are empty, as recognized by five bright dots corresponding to a pentagon of octahedra $\mathrm{MO}_{6}$ centered by a black patch. Similarly, filled PTs (PCs) are imaged as a pentagon of bright dots centered by a sixth bright $\operatorname{dot}$ (Figure 2a). The arrangement of the PCs in large areas corresponds to that of $\mathrm{Nb}_{8} \mathrm{~W}_{9} \mathrm{O}_{47}$ (Figure 1), e.g., in the upper half of Figure 2a. In the lower part of Figure 2a, a domain with a hitherto unobserved structure occurs, such as in the $\mathrm{Nb}_{8} \mathrm{~W}_{9} \mathrm{O}_{47}$ structure, where two differently oriented PC pairs are present (marked yellow and blue in Figure $2 b, c$ ). In this structure, they are oriented nearly perpendicular with respect to each other, so that two regularly arranged PCs are directly adjacent (red arrows in Figure 2d). While this close distance breaks the first rule proposed for a stable PC arrangement, it enables denser PC packing and, thus, a decrease in the oxygen/metal ratio $\mathrm{O} / \Sigma \mathrm{M}(\mathrm{M}=\mathrm{Nb}, \mathrm{W})$. A four-fold TTB supercell with $a=b=a_{\mathrm{TTB}}, c=c_{\mathrm{TTB}}$ describes this structure (Figure 2d). The metric of this cell is approximately tetragonal, but the peculiar PC arrangement decreases its symmetry to orthorhombic. In this cell, six of the sixteen PTs are occupied according to $(\mathrm{MO})_{6}\left(\mathrm{M}_{10} \mathrm{O}_{30}\right)_{4}$, or normalized to a single TTB unit (MO) $)_{1.5}\left(\mathrm{M}_{10} \mathrm{O}_{30}\right)$. Thus, the number of PCs is higher than in $\mathrm{Nb}_{8} \mathrm{~W}_{9} \mathrm{O}_{47}$, corresponding to (MO) $)_{1.33}\left(\mathrm{M}_{10} \mathrm{O}_{30}\right)$, which leads to a decreased ratio $\mathrm{O} / \Sigma \mathrm{M}: 2.739$ vs. 2.765. The general formula $(\mathrm{MO})_{6}\left(\mathrm{M}_{10} \mathrm{O}_{30}\right)_{4}$ corresponds to the composition $\mathrm{Nb}_{12} \mathrm{~W}_{11} \mathrm{O}_{63}$, which is that of the so-called 6:11 phase $\left(6 \mathrm{Nb}_{2} \mathrm{O}_{5}: 11 \mathrm{WO}_{3}\right)$ [15]. Interestingly, the structural model contains TTB cells in which all four PTs are empty, as indicated by red frames in Figure 2d, which is an array that does not occur in the $\mathrm{Nb}_{8} \mathrm{~W}_{9} \mathrm{O}_{47}$ structure. These empty TTB units and the units in which two PTs are occupied (blue PC pairs) are alternatingly arranged in the structural model of $\mathrm{Nb}_{12} \mathrm{~W}_{11} \mathrm{O}_{63}$ (Figure 2d). The domains of $\mathrm{Nb}_{8} \mathrm{~W}_{9} \mathrm{O}_{47}$ and $\mathrm{Nb}_{12} \mathrm{~W}_{11} \mathrm{O}_{63}$ are intimately intergrown with each other by sharing a slab of PC pairs (yellow in Figure $2 \mathrm{c}$ ) that run along the crystallographic a axis of $\mathrm{Nb}_{8} \mathrm{~W}_{9} \mathrm{O}_{47}$. The domain of the new structure is terminated on the left side by a defective area, which contains the blue PC pairs as a slab in a perpendicular orientation.

A larger area, which mainly contains the $\mathrm{Nb}_{8} \mathrm{~W}_{9} \mathrm{O}_{47}$ structure, is shown in Figure 3. Two distinct defects that are typical for this structure occur, namely, an out-of-phase boundary on the lower left side and rotational twinning by $90^{\circ}$ on the right side. The three-fold TTB superstructure is perfectly ordered on the upper left side (Figure 3a). The inclusion of a row of five PC pairs with perpendicular orientation (blue) causes a shift of the adjacent domains of $\mathrm{Nb}_{8} \mathrm{~W}_{9} \mathrm{O}_{47}$ by $1 / 3 \mathbf{b}\left(=\mathbf{b}_{\text {TTB }}\right)$, with respect to each other (Figure $3 \mathbf{b}, \mathbf{c}$ ). In the lower part of the boundary, the structure is semiregular; the slabs of yellow PC pairs in the two domains are connected via a chain of four diamond-linked PCs, with each 
slab contributing two PCs. The slabs with green PC pairs are not connected; instead, they directly neighbor an isolated yellow PC.

This structure is depicted on the lower left side of Figure 4a. Four-membered PC chains had been observed before, e.g., in zigzag out-of-phase and twin boundaries in $\mathrm{Nb}_{8} \mathrm{~W}_{9} \mathrm{O}_{47}$ [3] and as a regular structural element in $\mathrm{Nb}_{6} \mathrm{~W}_{8} \mathrm{O}_{39}$ (Figure 1) [4]. At the top of this boundary, the occupation of PTs is less regular and includes a three-membered PC chain, in which the middle PC belongs to two perpendicularly oriented slabs of PC pairs (blue and green). Here, a small block of six PCs with perpendicular orientation $\left(90^{\circ}\right.$ rotation twin) is incorporated (light blue area). Interestingly, this block connects two slabs of green PC pairs, and the two PCs at the top and at the bottom can be regarded as part of the small section of three PC pairs (light blue area) as well as part of the connected slabs of green PCs.

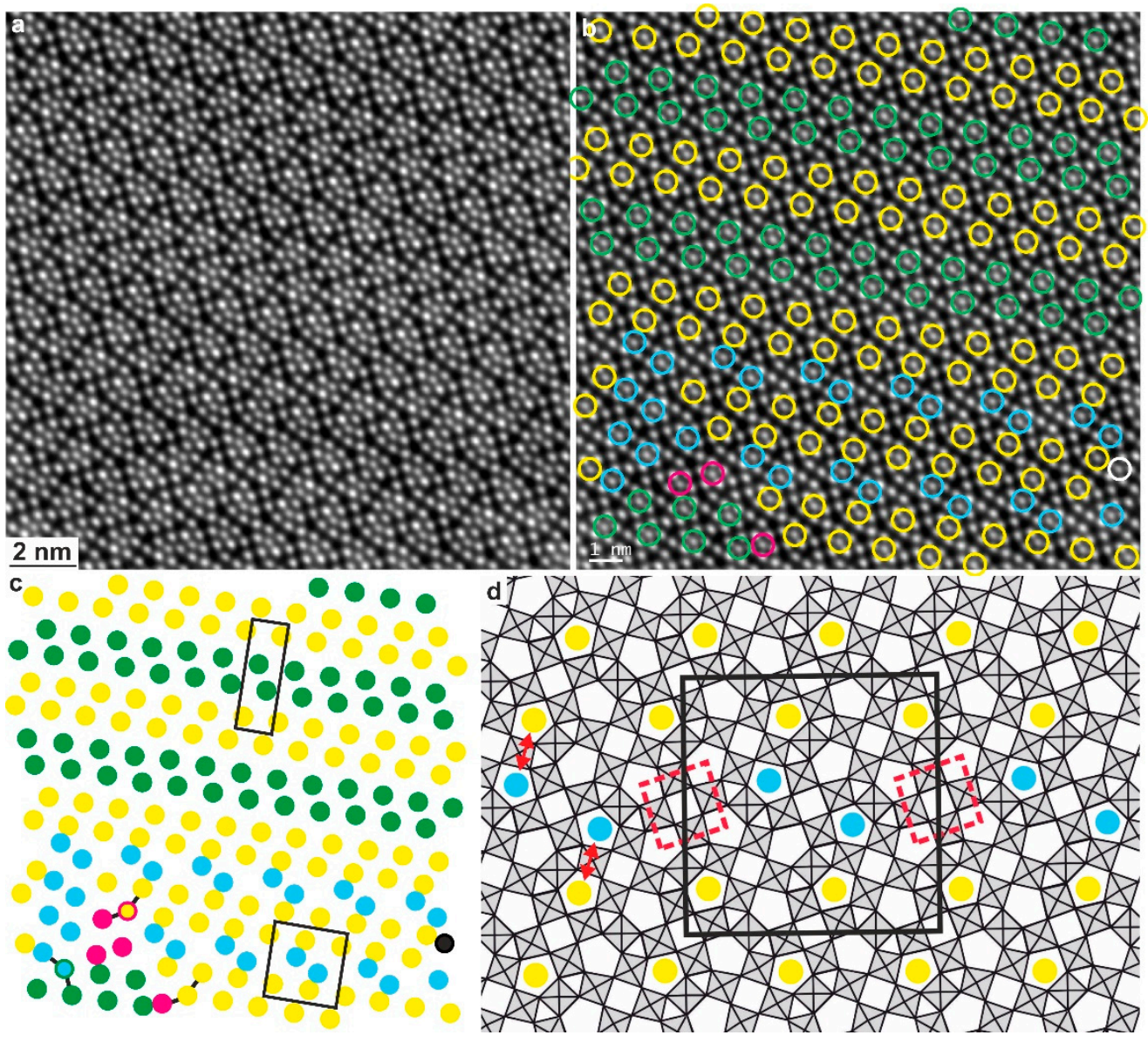

Figure 2. (a) HAADF-STEM image of $\mathrm{Nb}_{18} \mathrm{~W}_{16} \mathrm{O}_{93}$ recorded along [1] (courtesy of Prof. L. Shen, Nanjing) and (b) with the filled PTs marked as open circles. Pairs of diamond-linked pentagonal columns (PC) with the same orientation have the same color. (c) Scheme of the PCs with unit cells of $\mathrm{Nb}_{8} \mathrm{~W}_{9} \mathrm{O}_{47}$ (top) and $\mathrm{Nb}_{12} \mathrm{~W}_{11} \mathrm{O}_{63}$ (bottom) outlined. (d) Structural model of $\mathrm{Nb}_{12} \mathrm{~W}_{11} \mathrm{O}_{63}$. Red double arrows mark two directly adjacent PCs, and dashed squares mark empty TTB units. For details, see text. Figure 2a has been published in modified form as Figure 2e in [12] under CC-BY license.

Another example for such rotational twinning appears on the right side of Figure 3, with the corresponding structural model shown in Figure $4 \mathrm{~b}$. In the upper part, slabs of blue and magenta PC pairs are connected to perpendicularly oriented slabs of green and yellow PC pairs. This arrangement is frequently observed at boundaries between rotational twin domains; the central PC of a triple PC chain belongs to the two perpendicular PC slabs. This is also the case for the isolated PC that is quasi an extension of the PC rows that 
are not directly connected. This frequently appearing array is marked by dotted lines in Figure $4 \mathrm{~b}$ (top center) for the two units just described. It should be mentioned that such a connection of $90^{\circ}$ rotational twin domains by three-membered PC chains was already observed in the first HRTEM investigation of this material in 1974 [3]. Similarly to here, an empty TTB cell and directly adjacent simultaneously occupied PTs were found.

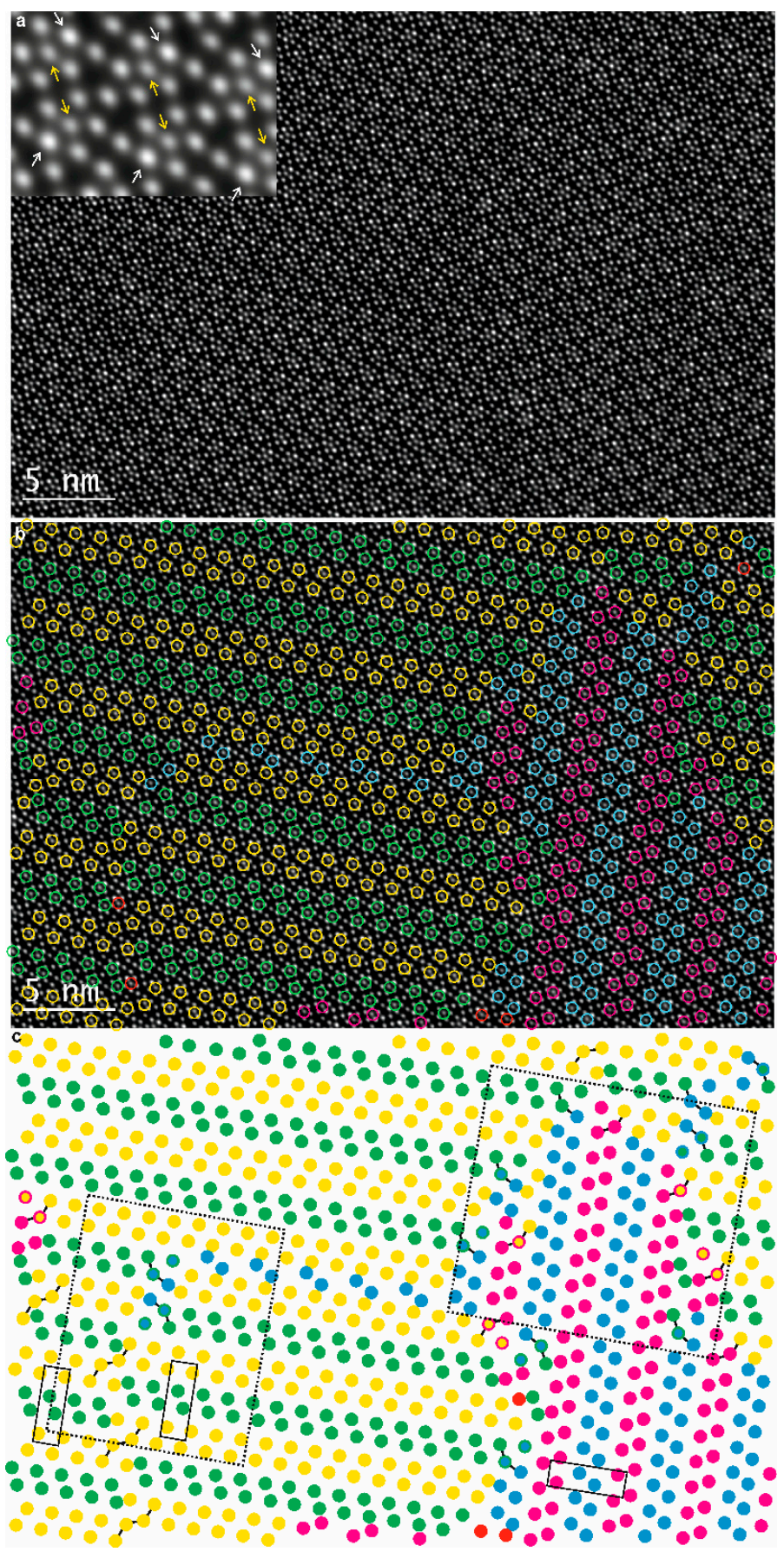

Figure 3. (a) HAADF-STEM image of $\mathrm{Nb}_{18} \mathrm{~W}_{16} \mathrm{O}_{93}$ recorded along [1] (courtesy of Prof. L. Shen, Nanjing) and (b) with the filled pentagonal tunnels (PTs) marked as open circles. (c) Scheme of the PT array. Rectangles framed by solid lines indicate unit cells of $\mathrm{Nb}_{8} \mathrm{~W}_{9} \mathrm{O}_{47}$ and those framed by dotted lines represent the areas interpreted in Figure 4. The magnified area (inset in (a)) demonstrates the varying dot intensities with white arrows pointing to $\mathrm{W}$-rich positions and yellow arrows to $\mathrm{Nb}$-rich positions. 

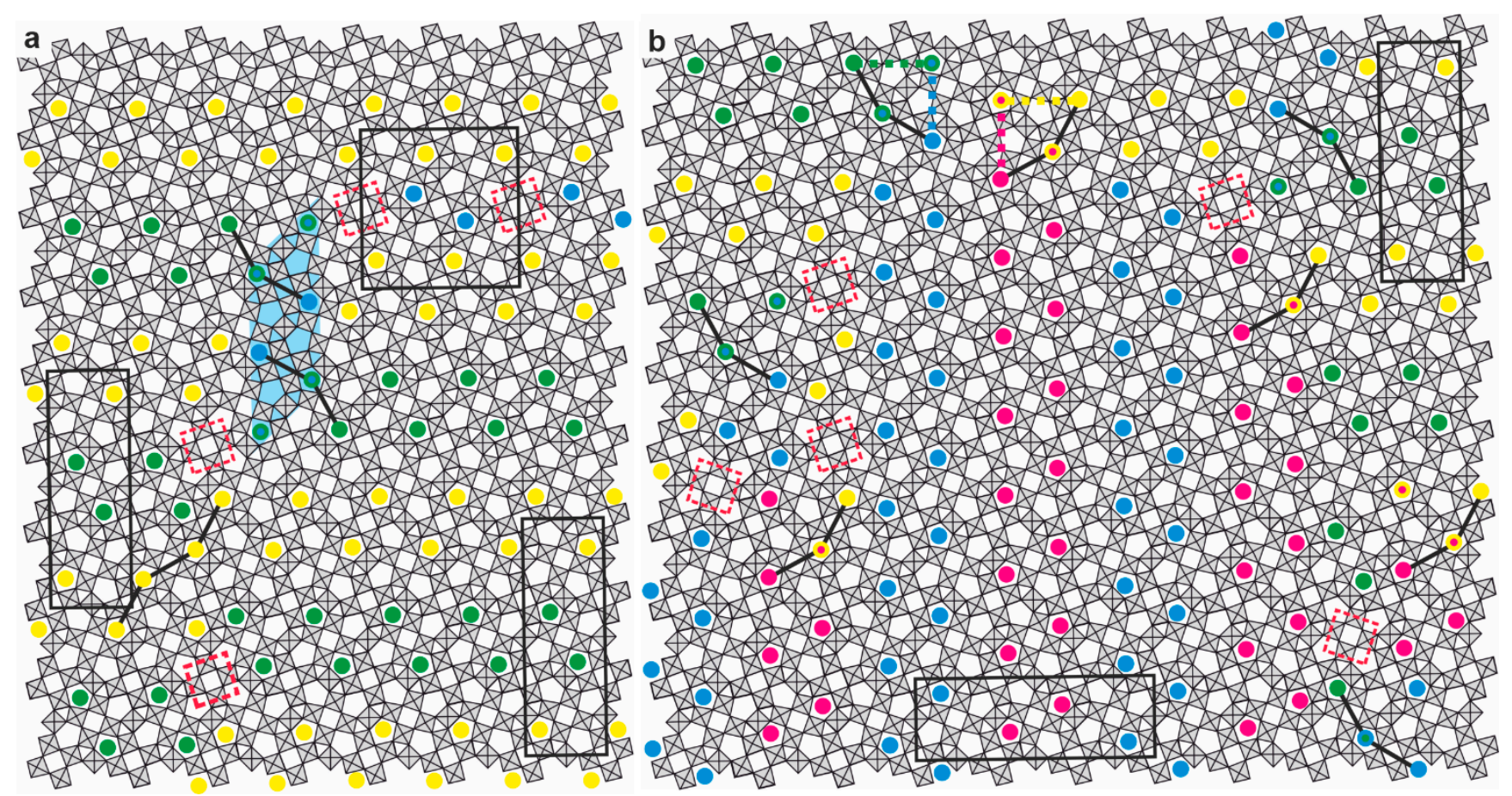

Figure 4. Structural models of the area (a) in the lower left corner and (b) in the upper right of Figure 3a. Some unit cells of $\mathrm{Nb}_{8} \mathrm{~W}_{9} \mathrm{O}_{47}$ and $\mathrm{Nb}_{12} \mathrm{~W}_{11} \mathrm{O}_{63}$ are framed black, and TTB subcells with four empty PTs are dotted red. In the lower part of (a), a grain boundary is present between domains of the $\mathrm{Nb}_{8} \mathrm{~W}_{9} \mathrm{O}_{47}$, which are shifted by $1 / 3 \mathbf{b}$ with respect to each other. In (b) domains of $\mathrm{Nb}_{8} \mathrm{~W}_{9} \mathrm{O}_{47}$ are rotated by $90^{\circ}$.

As the HAADF-STEM method generates images with the intensity $I$ increasing with the atomic number $Z\left(I \sim Z^{2} ; Z\right.$ contrast imaging $\left.[23,24]\right)$, the metal positions appear as bright dots, with their brightness increasing with the $\mathrm{W}$ content of the particular atomic column $\left(Z_{W}=74>Z_{N b}=41\right)[19,21]$. Thus, the observation of the relative brightness of the individual atomic columns in regions of constant thickness provides some information about the distribution of the metals (inset in Figure 3a). The relative darkness of the metal position inside the PTs indicates that it is preferentially occupied by $\mathrm{Nb}$, as is also the case in $\mathrm{W}$-richer samples [21]. Thus, the preference of $\mathrm{Nb}$ for this position, as it was found during the structure determination of $\mathrm{Nb}_{8} \mathrm{~W}_{9} \mathrm{O}_{47}$ from single-crystal X-ray diffraction data [18,25], has been preserved. This is also the case for a W-rich position that appears with high brightness (inset in Figure 3a).

The inclusion of structural units with directly adjacent PCs is a necessary means to account for the increased number of occupied PTs compelled by the decreased ratio $\mathrm{O} / \Sigma \mathrm{M}$. This observation is corroborated by determining the ratio $\mathrm{O} / \Sigma \mathrm{M}$ of a rather large crystal fragment (Figure 5). As already observed in the fragments described above, this region comprises small domains with the structures of $\mathrm{Nb}_{8} \mathrm{~W}_{9} \mathrm{O}_{47}$ and $\mathrm{Nb}_{12} \mathrm{~W}_{11} \mathrm{O}_{63}$, which are intimately intergrown with each other and appear in different orientations. The occupied PTs in this large area were detected (Figure 5b) and counted. The whole area contains 1345 TTB cells, in which 1876 PTs are occupied. Therefore, the overall composition is $(\mathrm{MO})_{1876}\left(\mathrm{M}_{10} \mathrm{O}_{30}\right)_{1345}$, with a ratio $\mathrm{O} / \Sigma \mathrm{M}=2.755$. This value is larger than that of the sample $\mathrm{Nb}_{18} \mathrm{~W}_{16} \mathrm{O}_{93}$, with $\mathrm{O} / \Sigma \mathrm{M}=2.735$, but significantly smaller than that of $\mathrm{Nb}_{8} \mathrm{~W}_{9} \mathrm{O}_{47}$, with $\mathrm{O} / \Sigma \mathrm{M}=2.765$.

\section{Discussion}

According to the evaluation of the HAADF-STEM images, the sample $\mathrm{Nb}_{18} \mathrm{~W}_{16} \mathrm{O}_{93}$ comprises an intact TTB framework that hosts intimately intergrown domains of the $\mathrm{Nb}_{8} \mathrm{~W}_{9} \mathrm{O}_{47}$ phase, with an increased amount of filled PTs. In the latter domains, the occupation of directly neighbored PTs by MO strings compensates for the decreased $\mathrm{O} / \Sigma \mathrm{M}$, 
as follows: $(\mathrm{MO})_{\mathrm{x}}\left(\mathrm{M}_{10} \mathrm{O}_{30}\right)$ with $\mathrm{x}>4 / 3$ compared to $\mathrm{x}=4 / 3$ in $\mathrm{Nb}_{8} \mathrm{~W}_{9} \mathrm{O}_{47}$. This is the case in the structure of $\mathrm{Nb}_{12} \mathrm{~W}_{11} \mathrm{O}_{63}\left(=(\mathrm{MO})_{6}\left(\mathrm{M}_{10} \mathrm{O}_{30}\right)_{4}\right.$ with $\left.\mathrm{x}=1.5\right)$ that has been observed in small domains in the sample $\mathrm{Nb}_{18} \mathrm{~W}_{16} \mathrm{O}_{93}$ for the first time. In fact, the ratio $\mathrm{O} / \Sigma \mathrm{M}$ of $\mathrm{Nb}_{12} \mathrm{~W}_{11} \mathrm{O}_{63}$ (2.739) is close to that of $\mathrm{Nb}_{18} \mathrm{~W}_{16} \mathrm{O}_{93}$ (2.735). This dense occupation of PTs, violating the first rule for a stable array of PCs, is enforced by the decreased $\mathrm{O}$ content that must be somehow adjusted by structural adaptions. Nonetheless, the most stable PC arrangement, namely, that of $\mathrm{Nb}_{8} \mathrm{~W}_{9} \mathrm{O}_{47}$, is still the dominating structure in the sample $\mathrm{Nb}_{18} \mathrm{~W}_{16} \mathrm{O}_{93}$, and is present in many domains, with a typical diameter of several $10 \mathrm{~nm}$. In contrast, the $\mathrm{O}$-poorer domains are smaller and heavily disordered, with regular structures appearing as rather small inclusions only. Both the TTB superstructures $\mathrm{Nb}_{8} \mathrm{~W}_{9} \mathrm{O}_{47}$ and $\mathrm{Nb}_{12} \mathrm{~W}_{11} \mathrm{O}_{63}$ do occur in different orientation variants (Figure $5 \mathrm{~b}$ ), with the respective nanometer-sized domains coherently intergrown with each other. This flexibility is caused by the unaffected TTB-type framework, with the structural modifications realized by filling PTs in different ways.

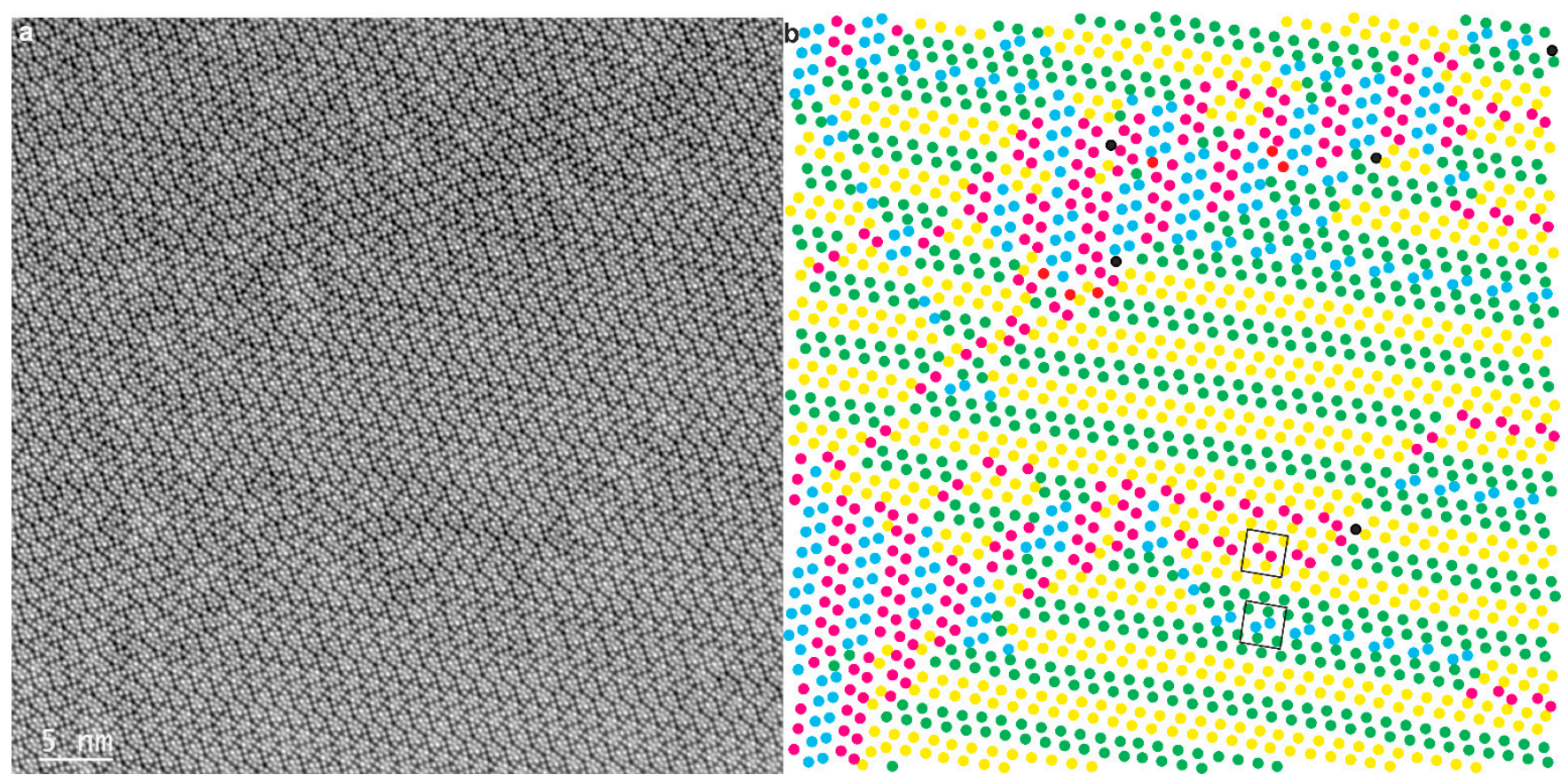

Figure 5. (a) HAADF-STEM image (courtesy of Prof. L. Shen, Nanjing) and (b) interpretation with PCs shown as filled circles. Two cells of $\mathrm{Nb}_{12} \mathrm{~W}_{11} \mathrm{O}_{63}$ in adjacent domains are framed.

Note that on the well-investigated W-rich side of $\mathrm{Nb}_{8} \mathrm{~W}_{9} \mathrm{O}_{47}(\mathrm{O} / \mathrm{SM}>2.765(=47: 17))$, the $\mathrm{O}$ surplus is accommodated by forming little ordered structures with a lower density of filled PTs. An example of this is the $\mathrm{Nb}_{6} \mathrm{~W}_{8} \mathrm{O}_{39}$ structure $(\mathrm{O} / \Sigma \mathrm{M}=2.786)$ with fourmembered PC chains (Figure 1) [4], which are intergrown with domains, or even single units, of $\mathrm{Nb}_{4} \mathrm{~W}_{7} \mathrm{O}_{31}(\mathrm{O} / \Sigma \mathrm{M}=2.818)[18,26]$. It is important to state that the PCs in all TTB-based structures and variants tend to be connected to form pairs or chains via the diamond link, rather than being isolated or directly adjacent. In the structure $\mathrm{Nb}_{12} \mathrm{~W}_{11} \mathrm{O}_{63}$, corresponding to $(\mathrm{MO})_{6}\left(\mathrm{M}_{10} \mathrm{O}_{30}\right)_{4}$, diamond-linked PCs pairs are directly adjacent to each other, which might represent a moderately stable arrangement, as it is present as an intact structure in nanodomains.

\section{Conclusions}

The present HAADF-STEM investigation reveals that the sample $\mathrm{Nb}_{18} \mathrm{~W}_{16} \mathrm{O}_{93}$ cannot be considered as a separate phase. The arrangement of PCs embedded in a perfectly ordered TTB substructure corresponds, in wide areas, to that of the well-known and stable phase $\mathrm{Nb}_{8} \mathrm{~W}_{9} \mathrm{O}_{47}$, but the arrangement is only slightly ordered in small domains. No 
evidence for the existence of a PC array, as suggested by Stephenson for the structure of $\mathrm{Nb}_{18} \mathrm{~W}_{16} \mathrm{O}_{93}$ [14] could be found. In general, most PCs are connected via the diamond link to form pairs or, less frequently, three- or four-membered chains of PCs. The decreased O content compared to $\mathrm{Nb}_{8} \mathrm{~W}_{9} \mathrm{O}_{47}$ is structurally compensated by denser packing of PTs filled with MO strings. This unavoidably leads to the occupation of directly adjacent PTs, similarly to how they are presented in the structural model proposed for $\mathrm{Nb}_{12} \mathrm{~W}_{11} \mathrm{O}_{63}$. This structure only appears in the investigated sample in nanometer-sized domains, but future synthetic efforts might be successful in preparing the $\mathrm{Nb}_{12} \mathrm{~W}_{11} \mathrm{O}_{63}$ phase in pure form.

Funding: This research was funded by ETH Zürich. This research received no external funding.

Institutional Review Board Statement: Not applicable.

Informed Consent Statement: Informed consent was obtained from all subjects involved in the study.

Data Availability Statement: Not applicable.

Acknowledgments: Sample preparation and HAADF-STEM imaging was performed in the Jiangsu Key Laboratory of Electrochemical Energy Storage Technologies at Nanjing University of Aeronautics and Astronautics, People's Republic of China. I am indebted to Laifa Shen for providing the HAADFSTEM images.

Conflicts of Interest: The author declares no conflict of interest.

\section{References}

1. Griffith, K.J.; Wiaderek, K.M.; Cibin, G.; Marbella, L.E.; Grey, C.P. Niobium tungsten oxides for high-rate lithium-ion energy storage. Nature 2018, 559, 556-563. [CrossRef]

2. Lundberg, M.; Sundberg, M.; Magnéli, A. The "pentagonal column" as a building unit in crystal and defect structures of some groups of transition metal compounds. J. Solid State Chem. 1982, 44, 32-40. [CrossRef]

3. Iijima, S.; Allpress, J.G. Structural studies by high-resolution electron microscopy: Tetragonal tungsten bronze-type structures in the system $\mathrm{Nb}_{2} \mathrm{O}_{5}-\mathrm{WO}_{3}$. Acta Crystallogr. A 1974, 30, 22-29. [CrossRef]

4. Krumeich, F. Order and disorder in niobium tungsten oxides of the tetragonal tungsten bronze type. Acta Crystallogr. B 1998, 54, 240-249. [CrossRef]

5. Marinder, B.-O.; Hörlin, T.; Magnéli, A. Structure and ionic conductivity of $\mathrm{Li}_{\mathrm{x}}(\mathrm{MeO})_{4} \mathrm{Me}_{30} \mathrm{O}_{90}\left(\mathrm{Me}=\mathrm{Nb}^{\mathrm{V}}, \mathrm{W}^{\mathrm{VI}}\right)$. Mater. Res. Bull. 1979, 14, 387-392. [CrossRef]

6. Montemayor, S.M.; Alvarez Mendez, A.; Martínez-de la Cruz, A.; Fuentes, A.F.; Torres-Martínez, L.M. Lithium insertion in two tetragonal tungsten bronze phases, $\mathrm{M}_{8} \mathrm{~W}_{9} \mathrm{O}_{47}(\mathrm{M}=\mathrm{Nb}$ and Ta). J. Mater. Chem. 1998, 8, 2777-2781. [CrossRef]

7. Martinez-de la Cruz, A.; Juarez Ramirez, I.; Torres Gonzalez, L.C. Electrochemical Li insertion in $\mathrm{Nb}_{8-\mathrm{x}} \mathrm{W}_{9+\mathrm{x}} \mathrm{O}_{47}(1 \leq \mathrm{x} \leq 6)$. Mater. Res. Bull. 2003, 38, 525-531. [CrossRef]

8. Ye, W.; Yu, H.; Cheng, X.; Zhu, H.; Zheng, R.; Liu, T.; Long, N.; Shui, V.; Shu, J. Highly efficient lithium container based on non-Wadsley-Roth structure $\mathrm{Nb}_{18} \mathrm{~W}_{16} \mathrm{O}_{93}$ nanowires for electrochemical energy storage. Electrochim. Acta 2018, 292, 331-338. [CrossRef]

9. Ma, X.-H.; Cheng, L.; Li, L.-L.; Cao, X.; Ye, Y.-Y.; Wei, Y.-Y.; Wu, Y.-D.; Sha, M.-L.; Zi, Z.-F.; Dai, J.-M. Influence of cut-off voltage on the lithium storage performance of $\mathrm{Nb}_{12} \mathrm{~W}_{11} \mathrm{O}_{63}$ anode. Electrochim. Acta 2020, 332, 135380. [CrossRef]

10. Lakhnot, A.S.; Gupta, T.; Singh, Y.; Hundekar, P.; Jain, R.; Han, F.; Koratkar, N. Aqueous lithium-ion batteries with niobium tungsten oxide anodes for superior volumetric and rate capability. Energy Storage Mater. 2020, 27, 506-513. [CrossRef]

11. Xia, R.; Sun, C.; Wang, Y.; Cunha, D.M.; Peng, H.; Zhao, K.; Huijben, M.; ten Elshof, J.E. Enhanced lithiation dynamics in nanostructured $\mathrm{Nb}_{18} \mathrm{~W}_{16} \mathrm{O}_{93}$ anodes. J. Power Sources 2021, 482, 228898. [CrossRef]

12. Dong, S.; Wang, Y.; Chen, C.; Shen, L.; Zhang, X. Niobium tungsten oxide in a green water-in-salt electrolyte enables ultra-stable aqueous lithium-ion capacitors. Nano-Micro Lett. 2020, 12, 168. [CrossRef]

13. Liu, W.; $\mathrm{Xu}, \mathrm{M} . ; \mathrm{Zhu}, \mathrm{M}$. Design of a niobium tungsten oxide/C micro-structured electrode for fast charging lithium-ion batteries. Inorg. Chem. Front. 2021, 8, 3998-4005. [CrossRef]

14. Stephenson, N.C. A structural investigation of some stable phases in the region $\mathrm{Nb}_{2} \mathrm{O}_{5} \cdot \mathrm{WO}_{3}-\mathrm{WO}_{3}$. Acta Crystallogr. B 1968, 24, 637-653. [CrossRef]

15. Roth, R.S.; Waring, J.L. Phase equilibria as related to crystal structure in the system niobium pentoxide-tungsten trioxide. J. Res. Natl Bur. Stand. 1966, 70A, 281-303. [CrossRef] [PubMed]

16. Horiuchi, S.; Muramatsu, K.; Matsui, Y. The crystal structure of $4 \mathrm{Nb}_{2} \mathrm{O}_{5} .9 \mathrm{WO}_{3}$ studied by 1 MV high-resolution electron microscopy. Acta Crystallogr. A 1978, 34, 939-946. [CrossRef]

17. Obayashi, H.; Anderson, J.S. Intermediate phases and pseudophases in the system $\mathrm{WO}_{3}-\mathrm{Nb}_{2} \mathrm{O}_{5}$ : Tetragonal tungsten bronze phases. J. Solid State Chem. 1976, 17, 79-89. [CrossRef] 
18. Wörle, M.; Krumeich, F. On the structural complexity of tetragonal tungsten bronze-type niobium tungsten oxides. Z. Anorg. Allg. Chem. 2021, 647, 98-106. [CrossRef]

19. Kirkland, A.I.; Meyer, R.R. "Indirect" high-resolution transmission electron microscopy: Aberration measurement and wavefunction reconstruction. Microsc. Microanal. 2004, 10, 401-413. [CrossRef]

20. Kirkland, A.I.; Saxton, W.O. Cation segregation in $\mathrm{Nb}_{16} \mathrm{~W}_{18} \mathrm{O}_{94}$ using high angle annular dark field scanning transmission electron microscopy and image processing. J. Microsc. 2002, 206, 1-6. [CrossRef] [PubMed]

21. Krumeich, F; Nesper, R. Oxidation products of the niobium tungsten oxide $\mathrm{Nb}_{4} \mathrm{~W}_{13} \mathrm{O}_{47}$ : A high-resolution scanning transmission electron microscopy study. J. Solid State Chem. 2006, 179, 1857-1863. [CrossRef]

22. Krumeich, F. Intergrowth of niobium tungsten oxides of the tetragonal tungsten bronze type. Z. Naturforsch. B 2020, 75, 913-919. [CrossRef]

23. Nellist, P.D. Principles of STEM imaging. In Scanning Transmission Electron Microscopy; Pennycook, S.J., Nellist, P.D., Eds.; Springer: New York, NY, USA, 2011; pp. 91-116.

24. Pennycook, S.J. Seeing the atoms more clearly: STEM imaging from the Crewe era to today. Ultramicroscopy 2012, $123,28-37$. [CrossRef] [PubMed]

25. Sleight, A.W. The crystal structure of $\mathrm{Nb}_{16} \mathrm{~W}_{18} \mathrm{O}_{94}$, a member of a $(\mathrm{MeO})_{\mathrm{x}} \mathrm{MeO}_{3}$ family of compounds. Acta Chem. Scand. 1966, 20, 1102-1112. [CrossRef]

26. Iijima, S.; Allpress, J.G. Structural studies by high-resolution electron microscopy: Coherent intergrowth of the $\mathrm{ReO}_{3}$ and tetragonal tungsten bronze structure types in the system $\mathrm{Nb}_{2} \mathrm{O}_{5}-\mathrm{WO}_{3}$. Acta Crystallogr. A 1974, 30, 29-36. [CrossRef] 